\title{
Conquerors or exiles? Impact of interference competition among invasive Ponto-Caspian gammarideans on their dispersal rates
}

\author{
Jarosław Kobak $\cdot$ Michał Rachalewski • \\ Karolina Bącela-Spychalska
}

Received: 7 August 2015/Accepted: 12 April 2016/Published online: 20 April 2016

(C) The Author(s) 2016. This article is published with open access at Springerlink.com

\begin{abstract}
Ponto-Caspian gammarids have invaded European waters, affecting local communities by predation and competition. Their ranges and dispersal rates vary across Europe, which may result from their interspecific interactions, accelerating or reducing migrations. We checked this hypothesis by testing interference competition among co-occurring invaders: Dikerogammarus villosus, D. haemobaphes and Pontogammarus robustoides. We used 140-cm long tanks (gravel substratum), divided into seven compartments. We introduced 25 "residents" into the outermost compartment, separated with a barrier. After $1 \mathrm{~h}$, we introduced 25 "intruders". After the next $1 \mathrm{~h}$, we removed the barrier and the gammarids dispersed in the tank. After 4 or $20 \mathrm{~h}$, we counted the gammarids in the compartments. We tested all pairwise species combinations and single-species controls. Dikerogammarus villosus displaced other species ( $P$. robustoides only after $4 \mathrm{~h}$ ) and reduced its own motility after $20 \mathrm{~h}$ in their presence. Pontogammarus robustoides stimulated the short-time migrations of $D$. villosus intruders and of D. haemobaphes. As $P$. robustoides migrated
\end{abstract}

J. Kobak $(\bowtie)$

Department of Invertebrate Zoology, Faculty of Biology and Environmental Protection, Nicolaus Copernicus University, Toruń, Poland

e-mail: jkob73@umk.pl

M. Rachalewski · K. Baccela-Spychalska

Department of Invertebrate Zoology and Hydrobiology,

University of Lodz, Lodz, Poland spontaneously much more than Dikerogammarus spp., its impact decreased after longer time. Dikerogammarus haemobaphes stimulated the short-time movement of $P$. robustoides intruders but reduced the longtime relocation of this species. In general, gammarid dispersal increased in the presence of stronger competitors (D. villosus and P. robustoides, especially residents) and decreased in response to weaker competitors (D. haemobaphes). Thus, competitive interactions may affect dispersal of invasive gammarids and contribute to the fastest spread of the weakest competitor, D. haemobaphes observed in the field, whereas the strongest species, D. villosus was the latest newcomer in many novel areas.

Keywords Dikerogammarus - Pontogammarus . Spatial partitioning $\cdot$ Species displacement . Migrations · Invasion potential

\section{Introduction}

Spatial distribution and co-occurrence of species at the microhabitat scale is a result of intra- and interspecific interactions (Waser 1985). The closer related species and the more their ecological niches overlap, the more competitive interactions can be expected, and their coexistence at the long time scale is suggested to be impossible even if a short time co-occurrence has been observed (Chase and Leibold 2003; Snyder and 
Chesson 2003). Individuals compete for the same resources which may be categorized as food or space including shelters against predators. Interference competition is observed when animals actively defend their inhabited territory including aggressive behaviour leading to injuries of the competitors (Schoener 1983). A specific type of this interaction is an intraguild predation (IGP) in which competitors representing the same guild prey on each other (Polis et al. 1989). It is known that asymmetrical IGP, when one of the species preys more efficiently on the other, strongly influences habitat selection by species in an ecosystem (Heithaus 2001). The stronger competitor and/or predator makes the weaker one to leave preferable habitats and shift to less favourable ones (e.g. Otsuki and Yano 2014). The outcompeted individuals increase their activity, even facing the risk of being preyed by a top predator or not finding an alternative suitable space to live (e.g. Shurin and Allen 2001). If the fragile species is not successful in finding a new territory, its population may decline, but in heterogeneous environments such interaction usually results in spatial partitioning of habitats by the species (reviewed in Amarasekare 2003). This avoidance of unfavourable conditions, including competition and/ or predation is one of the main drivers of species dispersal (e.g. Ronce 2007). Thus, considering the above, one may expect the weaker competitor exhibits a higher dispersal rate. On the other hand, several studies showed that individuals in worse physiological condition started their density or food dependent dispersal later and moved over shorter distances than strong, healthy (thus more competitive) individuals (e.g. Bonte and de la Pena 2009; Delgado et al. 2010).

Biological invasions, which are nowadays one of the major threats to global biodiversity (e.g. Lambertini et al. 2011), are one of the greatest opportunities to study mechanisms and consequences of species dispersal (e.g. Van Riel et al. 2007, 2011). The invasive freshwater amphipods may serve as a model group for such studies. Several amphipod species with relatively similar ecological niches successfully spread into European waters (Bij de Vaate et al. 2002; Grabowski et al. 2007b). They did not colonize the same water bodies at the same time, and a sequence of invasions of particular species can be observed (e.g. Holdich and Pöckl 2007; Grabowski et al. 2007b). In most cases the newcomer significantly moderated the community structure (e.g. Dick and Platvoet 2000; Jażdżewski et al. 2004; Krisp and Maier 2005; Kinzler et al. 2009; Chen et al. 2012; Truhlar and Aldridge 2015). In addition, several field studies showed spatial segregation of gammarid species, suggesting a habitat shift in the presence of related species (Kley and Maier 2005; MacNeil and Platvoet 2005; Hesselschwerdt et al. 2008; Żytkowicz and Kobak 2008; Platvoet et al. 2009; own unpublished data). Also experimental studies confirmed increasing swimming activity and movement of a "weaker" species (e.g. Gammarus pulex, G. tigrinus and Pontogammarus robustoides) to a different substratum in the presence of a stronger gammarid competitor (here Dikerogammarus villosus) (Van Riel et al. 2007; Platvoet et al. 2009; Jermacz et al. 2015a). These outcompeted taxa were also observed more often in a drift (Van Riel et al. 2011) or penetrating waters still not invaded by the other species, going upstream the river or entering affluents (Kley and Maier 2006), which might suggest their higher affinity for dispersal.

The influence of interference interactions on dispersal abilities of invasive amphipods has not been studied experimentally. We focused our study on three Ponto-Caspian gammarids (Dikerogammarus haemobaphes, D. villosus and Pontogammarus robustoides) which are widely distributed in Europe and their introduction has led to drastic changes in the macroinvertebrate community in colonized waters (Dick and Platvoet 2000; Arbaciauskas 2002; Jażdżewski et al. 2002, 2004; Berezina and Panov 2003). They are relatively large compared to native gammarids (Grabowski et al. 2007a) and exhibit several biological traits promoting their invasion, such as high reproductive abilities (reviewed in Grabowski et al. 2007a), opportunistic diet with effective predation (Platvoet et al. 2009; Bacela-Spychalska and Van der Velde 2013) as well as wide tolerance to ecological parameters (summarised in Bacela and Konopacka 2005; Rewicz et al. 2014; Bącela-Spychalska 2015).

Despite the fact that these species show slightly different preferences for hydrological conditions (Dedju 1980), they co-occur in many water bodies or were in contact in the past in native and invaded range (Carausu et al. 1955; Dedju 1980; Jażdżewski et al. 2004; Berezina 2007; Leuven et al. 2009). Although all the species could colonize new areas via similar routes (Bij de Vaate et al. 2002; Leuven et al. 2009), 
they did not start to spread and establish at the same time. Dikerogammarus haemobaphes, which was the first Dikerogammarus species expanding its range via all possible migration corridors (Jażdżewski 1980), after its successful establishment faced the subsequent invasion of $D$. villosus in many European rivers: the Danube, Rhine, Oder and Vistula. The latter species outnumbered its congener very efficiently in most of these waters (Kley and Maier 2003; Müller and Hertel 2004; own unpublished data). On contrary, in the UK, D. villosus was recorded first (2010) and D. haemobaphes was notified in two year time (Environment Agency 2012). Interestingly, in this case D. haemobaphes is more widespread and seems to be more successful (Environment Agency 2012; 2013). Pontogammarus robustoides, which is very abundant in dam reservoirs, lagoons and lentic sections of rivers, e.g. the Vistula and Oder, cohabits many sites with the two Dikerogammarus species (Baccela and Konopacka 2005; Żytkowicz et al. 2008; own unpublished data). All three gammarids, specifically adults, in experimental studies have exhibited similar, strong preferences for stony habitats (Devin et al. 2003; Van Riel et al. 2009; Boets et al. 2010; Jermacz et al. 2015b). Thus, in the case of co-occurrence, they are likely to interact strongly with one another.

In this study we intended to check if variable dispersal rates and sequences of appearance of particular invasive Ponto-Caspian gammarid species in different parts of Europe depend on their reciprocal interspecific interactions at localities in which they cooccur. We hypothesized that weaker species would increase their dispersal rate after the introduction of a stronger competitor, particularly D. villosus, the largest species among them (Rewicz et al. 2014). On the other hand, the presence of related species of similar ecological demands may also indicate the suitability of a given location and result in the decrease of dispersal, particularly of stronger competitors. It is known that an individual occupying a territory (resident) is more likely to win an interference competition than an intruder, trying to seize it (Grafen 1987; Jennions and Blackwell 1996). Thus, we also hypothesized that the outcome of the interaction between gammarid species would depend on the sequence of their introductions to the environment, with the newcomer being less likely to establish at a cohabited site and moving further.

\section{Materials and methods}

Animals

We collected Dikerogammarus villosus and Pontogammarus robustoides individuals from the Włocławek Reservoir (the lower River Vistula, Central Poland), N 52 $37^{\prime} 03^{\prime \prime}$, E $19^{\circ} 19^{\prime} 37^{\prime \prime}$ and D. haemobaphes from the Lucieńskie Lake, $\mathrm{N} 52^{\circ} 29^{\prime} 46^{\prime \prime}, \mathrm{E} 19^{\circ} 26^{\prime} 44^{\prime \prime}$. In the laboratory, we placed them in stock tanks (temperature $19-22^{\circ} \mathrm{C}$ ) with aerated and filtered water and fed daily with frozen chironomid larvae and commercial fish food pellets. They were used in experiments 1-4 weeks after collection. We assessed gammarid sizes with ImageJ 1.40 g software (W.S. Rasband, U.S. National Institutes of Health, Bethesda, Maryland, USA, http://rsb. info.nih.gov/i), using photographs of 100 randomly selected individuals from each species. Mean body length $\pm \mathrm{SD}$ of the studied individuals was $14.2 \pm 2.2 \mathrm{~mm}$ (D. villosus), $13.4 \pm 2.6 \mathrm{~mm}$ (P. robustoides) and $11.8 \pm 2.9 \mathrm{~mm}(D$. haemobaphes $)$, reflecting natural differences in body size between the species (Grabowski et al. 2007a).

Experimental setup

We conducted experiments in glass tanks $140 \mathrm{~cm}$ long and $15 \mathrm{~cm}$ wide, with the water level of $10 \mathrm{~cm}$ (Fig. 1). We divided the tank along its long axis into seven equal compartments and placed a Petri dish (diameter $12 \mathrm{~cm}$, height $1.5 \mathrm{~cm}$ ) filled with gravel (available commercially as aquarium substratum) in the centre of each compartment (Fig. 1). We measured the dimensions of 50 randomly selected gravel particles using ImageJ software. The gravel size, expressed as the means of the two perpendicular axes of the ellipses circumscribed on the particle shapes was $28.2 \pm 3.6 \mathrm{~mm}$. Gravel and stone substrata are known to be preferred by Dikerogammarus species (Van Riel et al. 2009; Boets et al. 2010) and P. robustoides (Jermacz et al. 2015b), thus we used this type substratum to induce a strong competition between them. We did not use other substrata as the three studied species show different preferences towards sand, macrophytes, etc. and this would lead to habitat partitioning and reduction of the competition, as shown by previous studies (Kley and Maier 2005; 


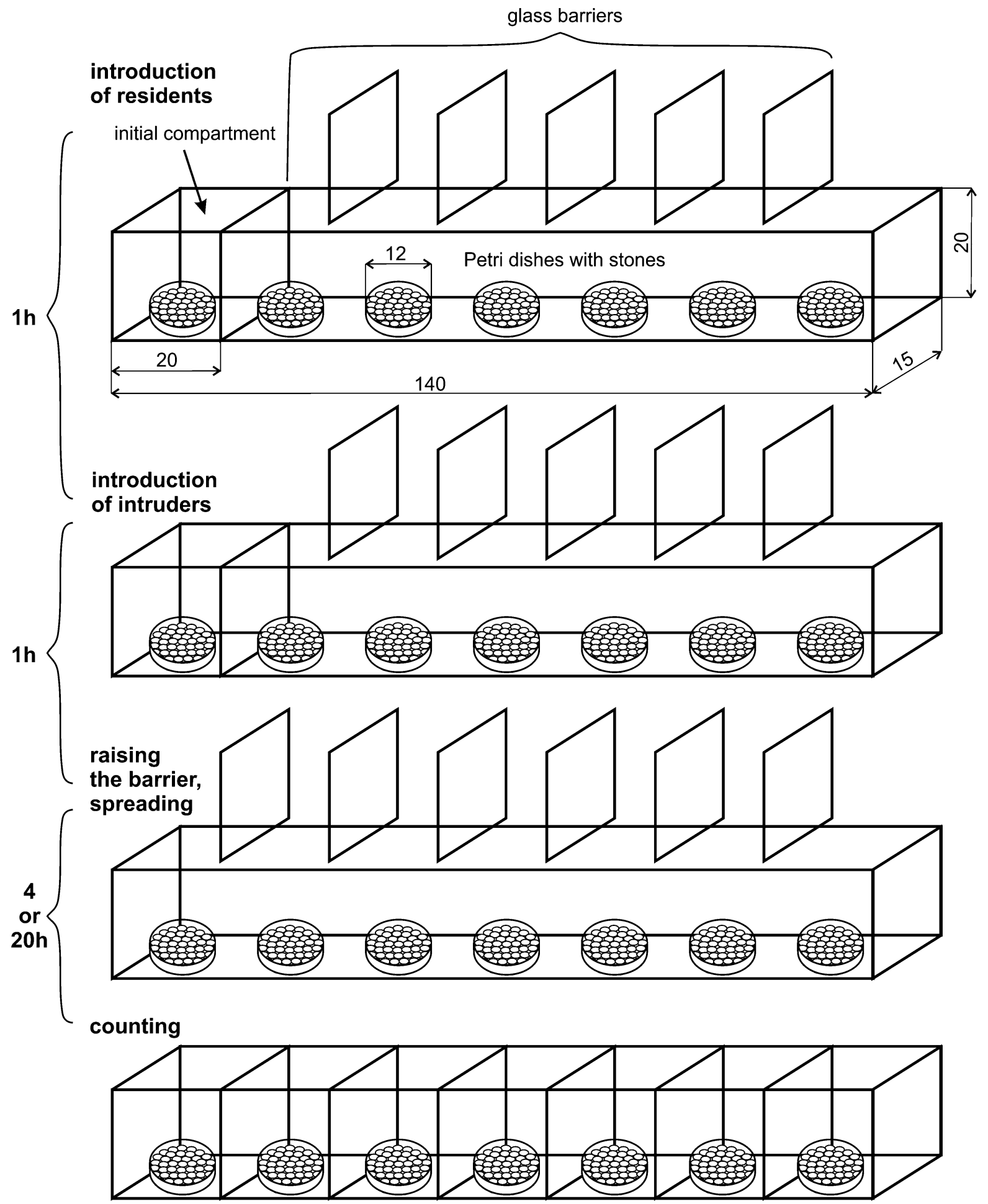

Fig. 1 Experimental tank and design. Dimensions are given in $\mathrm{cm}$ 
Table 1 Two-way ANOVA of gammarid behaviour

\begin{tabular}{|c|c|c|c|c|c|c|c|}
\hline & Dependent variable & Species & Factor & $d f$ & MS & $F$ & $P$ \\
\hline \multirow[t]{12}{*}{ A } & \multirow[t]{12}{*}{$\begin{array}{l}\% \text { of gammarids in the first } \\
\text { compartment }\end{array}$} & \multirow[t]{4}{*}{$P$. robustoides, all treatments } & $\begin{array}{l}\text { Accompanying } \\
\text { species }\end{array}$ & 4 & 0.12 & 9.87 & $<0.001$ \\
\hline & & & Exposure time & 1 & 0.09 & 7.40 & 0.008 \\
\hline & & & Interaction & 4 & 0.10 & 8.00 & $<0.001$ \\
\hline & & & Error & 90 & 0.01 & & \\
\hline & & \multirow[t]{4}{*}{ D. villosus, all treatments } & $\begin{array}{l}\text { Accompanying } \\
\text { species }\end{array}$ & 4 & 0.48 & 27.48 & $<0.001$ \\
\hline & & & Exposure time & 1 & 0.52 & 29.81 & $<0.001$ \\
\hline & & & Interaction & 4 & 0.11 & 6.38 & $<0.001$ \\
\hline & & & Error & 90 & 0.02 & & \\
\hline & & \multirow[t]{4}{*}{ D. haemobaphes, all treatments } & $\begin{array}{l}\text { Accompanying } \\
\text { species }\end{array}$ & 4 & 0.32 & 25.77 & $<0.001$ \\
\hline & & & Exposure time & 1 & 0.42 & 33.78 & $<0.001$ \\
\hline & & & Interaction & 4 & 0.08 & 6.14 & $<0.001$ \\
\hline & & & Error & 90 & 0.01 & & \\
\hline \multirow[t]{12}{*}{ B } & \multirow[t]{12}{*}{ Dispersal index } & \multirow[t]{4}{*}{$P$. robustoides, all treatments } & $\begin{array}{l}\text { Accompanying } \\
\text { species }\end{array}$ & 4 & 2.41 & 8.18 & $<0.001$ \\
\hline & & & Exposure time & 1 & 0.83 & 2.81 & 0.097 \\
\hline & & & Interaction & 4 & 1.76 & 5.98 & $<0.001$ \\
\hline & & & Error & 90 & 0.29 & & \\
\hline & & \multirow[t]{4}{*}{ D. villosus, all treatments } & $\begin{array}{l}\text { Accompanying } \\
\text { species }\end{array}$ & 4 & 11.17 & 37.90 & $<0.001$ \\
\hline & & & Exposure time & 1 & 11.65 & 39.54 & $<0.001$ \\
\hline & & & Interaction & 4 & 2.63 & 8.93 & $<0.001$ \\
\hline & & & Error & 90 & 0.29 & & \\
\hline & & \multirow[t]{4}{*}{ D. haemobaphes, all treatments } & $\begin{array}{l}\text { Accompanying } \\
\text { species }\end{array}$ & 4 & 10.07 & 48.34 & $<0.001$ \\
\hline & & & Exposure time & 1 & 8.90 & 42.72 & $<0.001$ \\
\hline & & & Interaction & 4 & 1.82 & 8.72 & $<0.001$ \\
\hline & & & Error & 90 & 0.21 & & \\
\hline \multirow[t]{4}{*}{$\mathrm{C}$} & \multirow{4}{*}{$\begin{array}{l}\% \text { of gammarids in the first } \\
\text { compartment }\end{array}$} & \multirow{4}{*}{$\begin{array}{l}\text { All species, single-species } \\
\text { treatments }\end{array}$} & Species & 2 & 0.37 & 18.58 & $<0.001$ \\
\hline & & & Exposure time & 1 & 1.23 & 61.96 & $<0.001$ \\
\hline & & & Interaction & 2 & 0.02 & 1.02 & 0.366 \\
\hline & & & Error & 54 & 0.02 & & \\
\hline \multirow[t]{4}{*}{ D } & \multirow[t]{4}{*}{ Dispersal index } & \multirow{4}{*}{$\begin{array}{l}\text { All species, single-species } \\
\text { treatments }\end{array}$} & Species & 2 & 8.51 & 32.52 & $<0.001$ \\
\hline & & & Exposure time & 1 & 25.26 & 96.55 & $<0.001$ \\
\hline & & & Interaction & 2 & 1.09 & 4.18 & 0.021 \\
\hline & & & Error & 54 & 0.26 & & \\
\hline
\end{tabular}

Impact of heterospecific gammarids on the behaviour of particular species (A, B) and behavioural differences among species in the single-species treatments $(\mathrm{C}, \mathrm{D})$

Jermacz et al. 2015a). On the other hand, in anthropogenically modified rivers, habitat heterogeneity is greatly impaired (Van Riel et al. 2007; Leuven et al. 2009) and possibilities of spatial segregation among species are lower, which may result in different responses, such as long distance migrations. Therefore, we intended to check gammarid behaviour in a uniform habitat to simulate such conditions. 
Dispersing species:

\begin{tabular}{|c|c|c|}
\hline Pontogammarus robustoides & Dikerogammarus villosus & Dikerogammarus haemobaphes \\
\hline short term long term & short term long term & short term long term \\
\hline
\end{tabular}

\section{Single-species treatments}

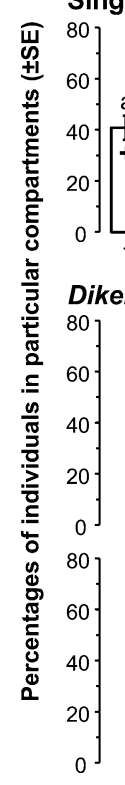

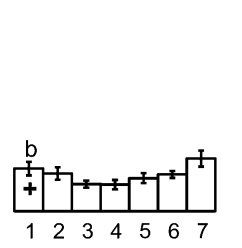
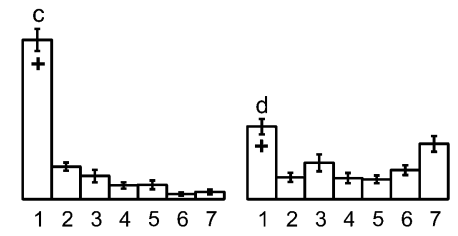

marus haemobaphes treatment
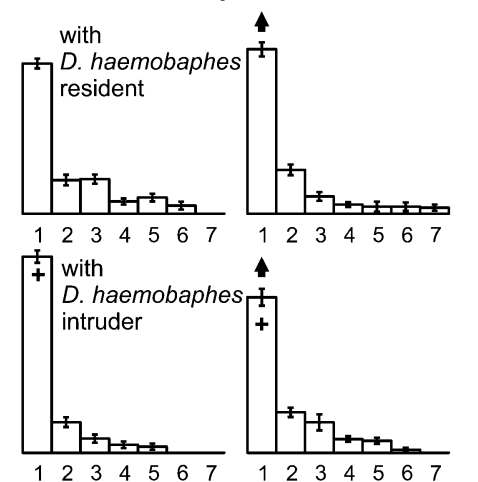

今

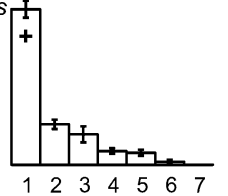

Pontogammarus robustoides vs. Dikerogammarus haemobaphes treatment

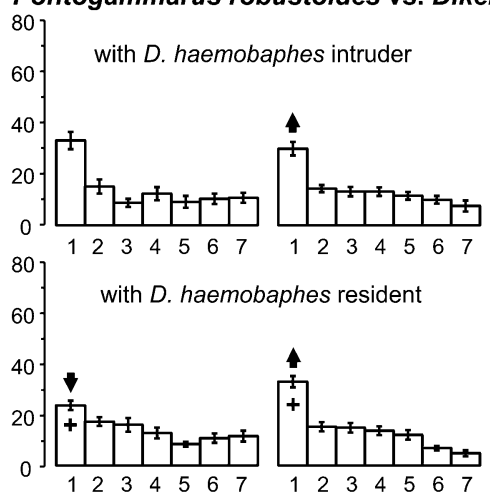

Pontogammarus robustoides vs. Dikerogammarus villosus treatment

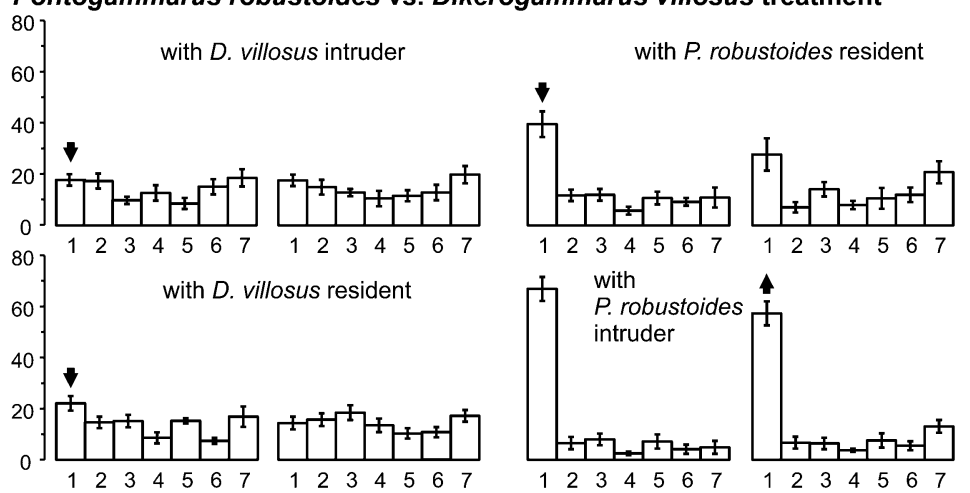

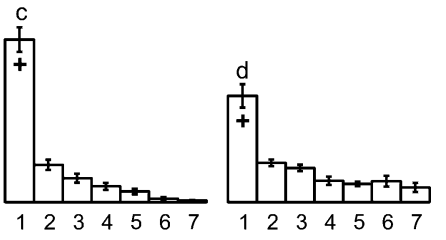

with $D$. villosus intruder

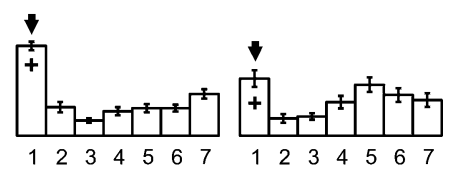

with $D$. villosus resident

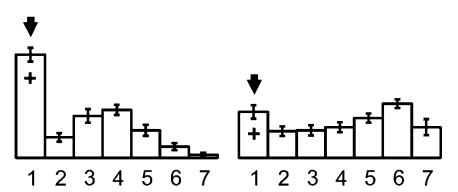

with $P$. robustoides resident
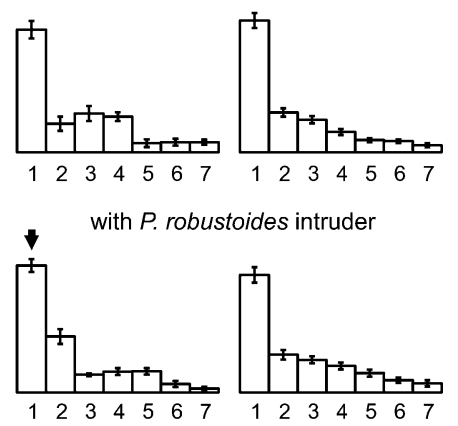

4 : significant differences (higher or lower values, respectively) between a given treatment and the corresponding single-species treatment

different letters abc: significant differences among species in the single-species treatments

+: significant differences

between the corresponding

short and long term treatments

Consecutive compartments ( 1 - initial compartment to which the gammarids were introduced) 
4Fig. 2 Distribution of gammarids in the compartments of the experimental tank in the presence of various competitors. Behavioural responses of particular species are shown in consecutive columns, whereas particular treatments are arranged in the same rows. Accompanying species are indicated on the plots. Arrows pointing upwards or downwards indicate that in a particular treatment the percentage of gammarids in the initial compartment was significantly higher or lower (respectively) than in the corresponding control single-species treatment. Plus ('+') signs indicate significant differences in gammarid percentages between the corresponding short and long term treatments. Different letters $(\mathrm{a}-\mathrm{c})$ above the bars of the single-species treatments indicate significant differences between the percentages of particular species in the initial compartment

Before the experiment, we separated the outermost compartment of the tank with a glass barrier and introduced 25 gammarid individuals, the "residents", to this compartment. After $1 \mathrm{~h}$, when the residents had established themselves in the substratum, we introduced the next 25 gammarids, the "intruders". The intruders were introduced to the substratum already occupied by the residents and had to outcompete them to take over the most suitable sites within the substratum. One hour is sufficient for gammarids to get used to experimental conditions and find a suitable shelter (Kinzler and Maier 2006). During subsequent manipulations, we observed that most of the individuals in our study were hidden in the substratum after $1 \mathrm{~h}$, which confirms this statement. We removed the barrier after the next $1 \mathrm{~h}$ and allowed the gammarids to spread freely all over the tank for $4 \mathrm{~h}$ (short-term trials) or $20 \mathrm{~h}$ (long-term trials). Finally, we separated all compartments with glass barriers and counted the gammarids (Fig. 1).

We tested all pairwise combinations of gammarid species, replicated 10 times, as well as single-species controls (with the same species used as a resident and intruder). Each individual was used only once in the experiment.

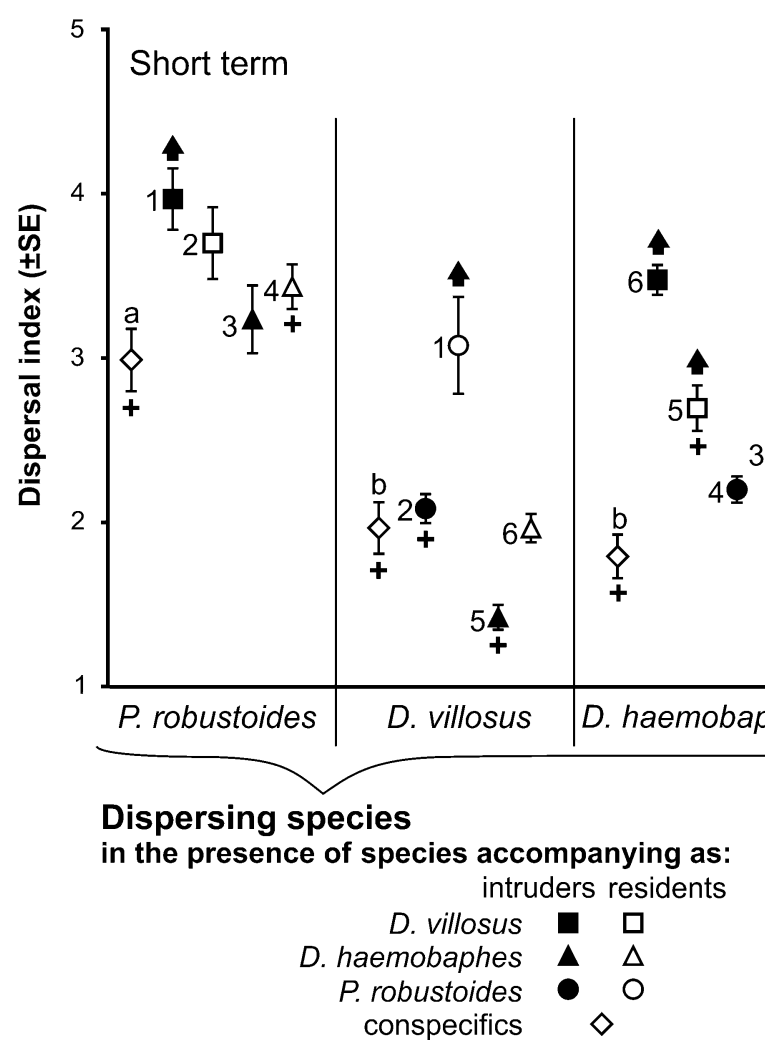

Fig. 3 Dispersal index showing the rate and distance of spread of gammarids from the initial compartment of the experimental tank in the presence of various competitors. Numbers 1-6
Long term

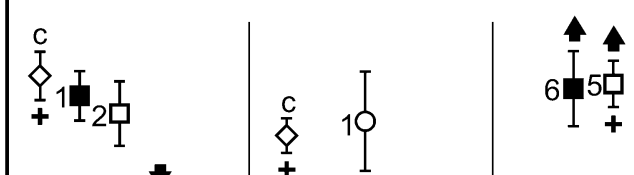

P. robustoides

D. villosus

D. haemobaphes

Numbers denote particular mixed-species treatments:

1 - D. villosus intruders vs. $P$. robustoides residents

2 - D. villosus residents vs. $P$. robustoides intruders

3 - D. haemobaphes intruders vs. $P$. robustoides residents

4 - $D$. haemobaphes residents vs. $P$. robustoides intruders

5 - D. haemobaphes intruders vs. $D$. villosus residents

6 - D. haemobaphes residents vs. $D$. villosus intruders

indicate particular mixed-species treatments. See Fig. 2 for the meanings of other symbols 
We conducted the experiments in darkness. Water quality parameters (mean $\pm \mathrm{SD}$ ), monitored with a multimeter Multi340i (WTW GmbH, Weilheim, Germany) were as follows: temperature $20.3 \pm 0.66^{\circ} \mathrm{C}$, $\mathrm{pH} 8.0 \pm 0.15$, conductivity $472 \pm 41.7 \mu \mathrm{S} / \mathrm{cm}$, oxygen saturation $72.7 \pm 8.46 \%$.

\section{Data analysis}

We analysed two dependent variables. The first variable was the percentage of individuals occupying the initial compartment of the tank, which allowed to determine the ability of gammarid species to displace one another from the occupied habitat. The second variable was a dispersal index (DI), calculated as the mean number of compartment occupied by all gammarids in the tank:

$\mathrm{DI}=\sum\left(\mathrm{N}_{\mathrm{i}} * \mathrm{i}\right) / \sum\left(\mathrm{N}_{\mathrm{i}}\right)$

where $\mathrm{N}_{\mathrm{i}}$ is the number of gammarids in the compartment $\mathrm{i}$ and $\mathrm{i}$ is the consecutive number of the compartment (1-7, with the number of the initial compartment $=1)$.

Such an index allowed to analyse the dispersal of gammarids in the entire tank and to distinguish between gammarid displacement to the nearby habitat (compartment) and stimulation of spread over a longer distance.

Percentage data were arcsine square root transformed prior to the analysis. It was not possible to include all the data into a single model because the results of the mixed-species treatments were not independent of each other (both species were together in the tank), whereas those from the single-species treatments could not be paired. Therefore, we conducted separate two-way ANOVAs for each gammarid species to test the effect of (1) Accompanying species (5 variable levels: a single-species control and two other gammarid species used as residents and intruders) and (2) Exposure time (long-term and shortterm trials). Moreover, we tested the differences in dispersal among gammarid species using a two-way ANOVA on the data from the single-species trials, with (1) Species (3 levels) and (2) Exposure time as factors. Significant ANOVA effects were followed by sequential-Bonferroni corrected t-tests used as a post hoc procedure.

\section{Results}

We did not observe any cases of intra-guild predation during the experiment, collecting the same numbers of individuals as had been introduced to the tanks. Behaviour of all gammarids depended on the accompanying species and exposure time, resulting in significant interactions between these factors in all analyses (Table 1A, B).

After the shorter exposure, individuals of Pontogammarus robustoides in the control treatment tended to remain near the place of their introduction. Dikerogammarus villosus forced them to move along the experimental tank, irrespective of the order of species introduction (Figs. 2, 3). The short-time effect of Dikerogammarus haemobaphes was similar to that of D. villosus, though less pronounced and limited only to the resident competitors and to the initial tank compartment (no significant effect for the dispersal index, Fig. 3). After the longer exposure, P. robustoides dispersed equally all over the tank in the control treatment and in the presence of $D$. villosus, but the presence of $D$. haemobaphes made them stay near their initial location relatively more often (Figs. 2, 3). Interestingly, the dispersal of $P$. robustoides in the presence of $D$. haemobaphes residents decreased significantly after the longer exposure compared to the short-time treatment, indicating that some individuals might return to the place of introduction after initial spreading (Fig. 2).

Dikerogammarus villosus did not respond to the short-term exposure to the other gammarids except their significant displacement by $P$. robustoides residents (Figs. 2, 3). After the longer exposure, individuals of $D$. villosus significantly decreased their dispersal in the presence of the other species and stayed in the initial compartment more often than in the control treatment.

After the short exposure, D. haemobaphes was forced to migrate along the tank by both heterospecific competitors, irrespective of their introduction status (Figs. 2,3). After the longer time, only the effect of $D$. villosus remained significant.

Gammarid behaviour in the single-species treatments differed significantly among the studied species. Both Dikerogammarus species left their initial locations less often than $P$. robustoides at both exposure times, resulting in a significant species effect 
in ANOVA (Table 1C). Also, all species were more dispersed after the longer exposure (Figs. 2, 3). However, after the longer exposure, D. villosus was distributed in the tank more uniformly than $D$. haemobaphes (Fig. 3), which remained mostly within the first three compartments (Fig. 2). This resulted in a significant species $\mathrm{x}$ exposure time interaction in the dispersal index analysis (Table 1D). With regard to this index, the short-term dispersal of $P$. robustoides was greater from that of both Dikerogammarus species, whereas after the longer exposure the distribution of $D$. haemobaphes was more limited to a few first tank compartments than that of the other two species (Fig. 3).

\section{Discussion}

Gammarids are highly motile organisms, which migrate in response to a number of factors, including food and predator cues (Wisenden et al. 2009), water flow (Dennert et al. 1969) and competitor pressure (Jermacz et al. 2015a). Moreover, their dispersal is influenced by human vectors, including biofouling of artificial surfaces (Martens and Grabow 2008; Davidson et al. 2009), intentional introductions (Arbaciauskas 2002) and overland transport (BacelaSpychalska et al. 2013; Bącela-Spychalska 2015). In our study, their dispersal rate differed between singlespecies and mixed-species treatments, which shows that the presence of related species is another factor influencing their movement and microhabitat occupancy. Our results support the hypothesis that, indeed, the weaker species is forced to leave its initial location and disperse more in the experimental tank. Dikerogammarus villosus, also called "the killer shrimp", is a very strong competitor (Dick and Platvoet 2000; Van der Velde et al. 2000; Kinzler and Maier 2003; MacNeil et al. 2011), capable of outcompeting other species to less preferable habitats (Van Riel et al. 2007; 2009; Jermacz et al. 2015a). In our experiments, it successfully displaced $D$. haemobaphes in all treatments and $P$. robustoides in the short term treatments. It pushed out the other species even as an intruder, probably due to its aggression and active fighting for a shelter (Dick and Platvoet 2000; Platvoet et al. 2009). Dikerogammarus villosus can also eliminate other amphipods by intraguild predation
(Kinzler and Maier 2003; MacNeil and Platvoet 2005; Kinzler et al. 2009) but we did not observe any predation in our experiments, so this factor did not affect gammarid dispersal in our study.

The strong competition between two Dikerogammarus spp. could result from their similar dispersal habits (shown in single-species trials), facilitating interspecific encounters. Another reason may be a close phylogenetic relationship between them (Cristescu and Hebert 2005). Species from the same genus are more likely to compete with each other than those from different genera, which results in phylogenetic overdispersion, which is the tendency of co-occurring species to be less related with one another than expected by chance (Cooper et al. 2008; CavenderBares et al. 2009; Vamosi et al. 2009).

Pontogammarus robustoides also seems effective in shelter guarding, as it did not allow D. villosus intruders to settle successfully in the short term treatment. Moreover, it is as predatory as the killer shrimp (Bacela-Spychalska and Van der Velde 2013) and its aggression may also be similar (own observations). On the other hand, in the single-species treatments, $P$. robustoides was more active and "explorative" than Dikerogammarus spp. Truhlar and Aldridge (2015) observed that D. villosus was also relatively less active and explorative than other gammarids (e.g. Gammarus pulex). That is why $P$. robustoides in our study left the initial compartment faster than the other species and therefore its impact on the long-term dispersal of $D$. haemobaphes was lower than that of $D$. villosus. Such a strong tendency for spontaneous dispersal enables $P$. robustoides to test a variety of available microhabitats and finally find a suitable site in a patchy environment. It occurs on a wide range of different substrata, such as macrophytes, tree roots, mussel beds, sand or gravel (Gruszka 1999; Kobak and Żytkowicz 2007), whereas Dikerogammarus spp. are limited to large-grain, hard substrata or mussel beds (Boets et al. 2010). Thus, P. robustoides seems best adapted to locate new suitable sites in its neighbourhood and can avoid excessive competition by relocation to alternative microhabitats (Jermacz et al. 2015a). However, its long-distance spread is limited by its avoidance of flowing waters (Jażdżewski et al. 2002).

Dikerogammarus villosus and P. robustoides, which seem the strongest competitors, in the long 
term single-species experiments spread more than in the presence of $D$. haemobaphes. It may be explained by defending local shelters by the stronger species in the presence of heterospecific interactions or by the weaker competition pressure from $D$. haemobaphes compared to that exerted by conspecifics. Interspecific competition is usually weaker than intraspecific competition (Connell 1983), and our results seem to be congruent with that hypothesis, though some exceptions from this rule do exist (Jermacz et al. 2015a).

Microhabitat heterogeneity allows competing species to co-exist when they can partition available space and avoid direct interactions (Hesselschwerdt et al. 2008; Platvoet et al. 2009; Koester and Gergs 2014). In our study, the gammarids could not switch to another microhabitat, but were able to avoid competition by dispersal. This reflects a common situation in highly regulated European rivers with decreased microhabitat diversity (Van Riel et al. 2007; Leuven et al. 2009), where weaker species would spread faster in the presence of stronger competitors. The outcompeted individuals may decline in a new area due to unsuitable local conditions, but their high invasive potential (a set of specific life history traits and wide ecological tolerance; Grabowski et al. 2007a) may allow them to thrive, leading to the faster increase of their range. A larger number of displaced individuals and/or more frequent displacement events would increase the probability of a successful invasion.

In the field, D. haemobaphes has often been observed to appear first, whereas D. villosus was the latest newcomer in most of the colonised water bodies. The spread of these species in the large part of the central migration corridor (the Dnieper, Prypiat, Bug and Vistula rivers, Bij de Vaate et al. 2002) followed that pattern. Dikerogammarus villosus appeared in the Vistula River system at least 4 years after $D$. haemobaphes (Konopacka 1998; Jażdżewski and Konopacka 2002; Jażdżewski et al. 2004; Grabowski et al. 2007b). In the Danube/Rhine river system, the invasion of both species was more simultaneous (Bij de Vaate et al. 2002), but D. haemobaphes more often spread to the affluents of the main rivers, whereas its congener was limited to the main rivers (Weinzierl et al. 1996; Kley and Maier 2003; own unpublished data). Such a pattern has usually been explained by the high dispersal rate of $D$. haemobaphes, being a "pioneer" species often colonising upstream the rivers
(Jażdżewski 1980). Our results, showing the weak dispersal of $D$. haemobaphes in the single-species treatments, shed new light on the history of invasion of the two Dikerogammarus spp., suggesting that competitive displacement may increase the dispersal rate of the weaker competitor and contribute to its fast spread. There, due to its highly invasive character, it can develop fast growing populations and outnumber native species (Jażdżewski et al. 2004; Grabowski et al. 2007a; Baccela-Spychalska and Van der Velde 2013).

A similar mechanism may help explain the invasion pattern of Echinogammarus ischnus, which was the first Ponto-Caspian gammarid colonising European inland waters (Jażdżewski 1980; Bij de Vaate et al. 2002). This species is also often outcompeted by later colonisers, such as D. villosus (Van Riel et al. 2006) and P. robustoides (Żytkowicz and Kobak 2008). Another example of that phenomenon is the case of invasive dreissenid mussels. The quagga mussel Dreissena rostriformis bugensis is a stronger competitor, gradually displacing the zebra mussel, Dreissena polymorpha when both species co-occur (Orlova et al. 2005), though the latter species is a faster colonizer with a wider range of occurrence in the early stage of invasion (Garton et al. 2013; Matthews et al. 2014).

Similar results of interactions between competitors (De Meester et al. 2014), as well as between intraguild prey and predators (Wang et al. 2013) were listed highlighting that the dispersal may be an efficient strategy leading to avoidance of adverse interactions between species. Interestingly, in most cases of biological invasions the fastest spreading species are regarded as the strongest competitors with the highest invasive potential (Lockwood et al. 2013). That is in contrast to the aforementioned phenomenon of the high dispersal rate exhibited by weaker competitors to decrease competitive pressure. Our results are congruent with the latter hypothesis, showing that negative interactions may promote spread of weaker species into novel areas, and thus contribute to their range extension.

Thus, we demonstrate two different potential mechanisms which may influence the dispersal of Ponto-Caspian gammarid species. Pontogammarus robustoides exhibits a natural tendency to explore new locations and spreads spontaneously even when 
not affected by heterospecific competitors. Dikerogammarus haemobaphes, on the other hand, displays a strong affinity for the inhabited territory, but migrates in response to the presence of stronger competitors. Both these mechanisms lead to similar results: greater probability of appearance of alien species in novel areas, which in consequence increases their ranges and invasive potential. In contrast to these species, active migrations of $D$. villosus seem relatively slower, which may explain its later appearance in many invaded areas.

In accordance with the "invasional meltdown" hypothesis, positive interactions among various alien species facilitate their establishment in newly invaded areas and therefore contribute to the success of biological invasions (Simberloff and von Holle 1999). We demonstrate that negative relationships among invaders may stimulate their spread to novel areas, thus constituting another important factor promoting biological invasions and explaining the sequence of colonization of new locations.

Acknowledgments The authors would like to thank Łukasz Jermacz and Kamil Hupało for help in collecting animals used in the experiments. The study was supported by National Science Centre Grants 2011/03/D/NZ8/03012 and 2012/05/B/NZ8/ 00479 .

Open Access This article is distributed under the terms of the Creative Commons Attribution 4.0 International License (http:// creativecommons.org/licenses/by/4.0/), which permits unrestricted use, distribution, and reproduction in any medium, provided you give appropriate credit to the original author(s) and the source, provide a link to the Creative Commons license, and indicate if changes were made.

\section{References}

Amarasekare P (2003) Competitive coexistence in spatially structured environments: a synthesis. Ecol Lett 6:1109-1122

Arbaciauskas K (2002) Ponto-Caspian amphipods and mysids in the inland waters in Lithuania: history of introduction, current distribution and relations with native malacostracans. In: Leppäkoski E, Gollasch S, Olenin S (eds) Invasive aquatic species of Europe-distribution, impacts and management. Kluwer Academic Publishers, Dordrecht, pp 104-115

Bạcela K, Konopacka A (2005) The life history of Pontogammarus robustoides (G.O. Sars, 1894)—an alien amphipod species in Polish waters. J Crustac Biol 25:190-195

Bącela-Spychalska K (2015) Attachment ability of two PontoCaspian amphipod species may promote their overland transport. Aquat Conserv Mar Freshw Ecosyst. doi:10. 1002/aqc. 2565

Bacela-Spychalska K, Van der Velde G (2013) There is more than one 'killer shrimp': trophic positions and predatory abilities of invasive amphipods of Ponto-Caspian origin. Freshw Biol 58:730-741

Bącela-Spychalska K, Grabowski M, Rewicz T, Konopacka A, Wattier R (2013) The "killer shrimp" Dikerogammarus villosus (Crustacea, Amphipoda) invading Alpine Lakes: overland transport by recreational boats and scuba-diving gear as potential entry vectors? Aquat Conserv Mar Freshw Ecosyst 23:606-618

Berezina NA (2007) Invasions of alien amphipods (Amphipoda: Gammaridea) in aquatic ecosystems of North-Western Russia: pathways and consequences. Hydrobiologia 590:15-29

Berezina NA, Panov VE (2003) Establishment of new gammarid species in the eastern Gulf of Finland (Baltic Sea) and their effects on littoral communities. Proc Estonian Acad Sci (Biol Ecol) 52:284-304

Bij de Vaate A, Jażdżewski K, Ketelaars HAH, Gollasch S, Van der Velde G (2002) Geographical patterns in range extension of Ponto-Caspian macroinvertebrate species in Europe. Can J Fish Aquat Sci 59:1159-1174

Boets P, Lock K, Messiaen M, Goethals PLM (2010) Combining data-driven methods and lab studies to analyse the ecology of Dikerogammarus villosus. Ecol Inform 5:133-139

Bonte D, de la Pena E (2009) Evolution of body conditiondependent dispersal in metapopulations. J Evol Biol 22:1242-1251

Cărăuşu S, Dobreanu E, Manolache C (1955) Amphipoda forme salmastre şi de apă dulce. Fauna Repub Pop Rom Crustacea 4:1-407

Cavender-Bares J, Kozak JKH, Fine PVA, Kembel SW (2009) The merging of community ecology and phylogenetic biology. Ecol Lett 12:693-715

Chase JM, Leibold MA (2003) Ecological niches. Linking classical and contemporary approaches. The University of Chicago Press, Chicago and London

Chen W, Bierbach D, Plath M, Streit B, Klaus S (2012) Distribution of amphipod communities in the Middle to Upper Rhine and five of its tributaries. Bioinvasions Rec 4:263-271

Connell JH (1983) On the prevalence and relative importance of interspecific competition: evidence from field experiments. Am Nat 122:661-696

Cooper N, Rodriguez J, Purvis A (2008) A common tendency for phylogenetic overdispersion in mammalian assemblages. Proc R Soc B 275:2031-2037

Cristescu MEA, Hebert PDN (2005) The "Crustacean Seas"an evolutionary perspective on the Ponto-Caspian peracarids. J Fish Aquat Sci 62:505-517

Davidson IC, Brown CW, Sytsma MD, Ruiz GM (2009) The role of containerships as transfer mechanisms of marine biofouling species. Biofouling 25:645-655

De Meester N, Derycke S, Rigaux A, Moens T (2014) Active dispersal is differentially affected by inter- and intraspecific competition in closely related nematode species. Oikos 124:561-570

Dedju, II (1980) Amfipody presnykh i solonovatykh vod yugozapada SSSR. Izdatelstvo "Shtiinca", Kishinev 
Delgado MM, Penteriani V, Revilla E, Nams VO (2010) The effect of phenotypic traits and external cues on natal dispersal movements. J Anim Ecol 79:620-632

Dennert HG, Dennert AL, Kant P, Pinkster S, Stock JH (1969) Upstream and downstream migrations in relation to the reproductive cycle and to environmental factors in the amphipod, Gammarus zaddachi. Bijdr Dierkd 39:11-43

Devin S, Piscart C, Beisel JN, Moreteau JC (2003) Ecological traits of the amphipod invader Dikerogammarus villosus on a mesohabitat scale. Arch Hydrobiol 158:43-56

Dick JTA, Platvoet D (2000) Invading predatory crustacean Dikerogammarus villosus eliminates both native and exotic species. Proc R Soc Lond Ser B Biol Sci 267:977-983

Environment Agency (2012) Invasive shrimp, Dikerogammarus haemobaphes. Interim Brief Note 1:1-4

Environment Agency (2013) Briefing note on the invasive shrimp, Dikerogammarus haemobaphes. Interim Brief Note 2:1-4

Garton DW, McMahon R, Stoeckmann AM (2013) Limiting environmental factors and competitive interactions between zebra and quagga mussels in North America. In: Nalepa TF, Schloesser DW (eds) Quagga and zebra mussels: biology, impacts, and control. CRC Press, Boca Raton, pp 383-402

Grabowski M, Bacela K, Konopacka A (2007a) How to be an invasive gammarid-comparison of life history traits. Hydrobiologia 590:75-84

Grabowski M, Jażdżewski K, Konopacka A (2007b) Alien Crustacea in Polish waters-Amphipoda. Aquat Invasions 2(1):25-38

Grafen A (1987) The logic of divisively asymmetric contests: respect of ownership and the desperado effect. Anim Behav 35:462-467

Gruszka P (1999) The River Odra Estuary as a gateway for alien species immigration to the Baltic Sea Basin. Acta Hydrochim Hydrobiol 27:374-381

Heithaus MR (2001) Habitat selection by predators and prey in communities with asymmetrical intraguild predation. Oikos 92:542-554

Hesselschwerdt J, Necker J, Wantzen KM (2008) Gammarids in Lake Constance: habitat segregation between the invasive Dikerogammarus villosus and the indigenous Gammarus roeselii. Fundam Appl Limnol 173:177-186

Holdich DM, Pöckl M (2007) Invasive crustaceans in European inland waters. In: Gherardi F (ed) Biological invaders in inland waters: profiles. Distribution and threats. Springer, Dordrecht, pp 29-75

Jażdżewski K (1980) Range extensions of some gammaridean species in European inland waters caused by human activity. Crustac Suppl 6:84-107

Jażdżewski K, Konopacka A (2002) Invasive Ponto-Caspian species in waters of the Vistula and Oder basins and the southern Baltic Sea. In: Leppäkoski E, Gollasch S, Olenin $\mathrm{S}$ (eds) Invasive aquatic species of Europe-distribution, impacts and management. Kluwer Academic Publishers, Dordrecht, pp 384-398

Jażdżewski K, Konopacka A, Grabowski M (2002) Four PontoCaspian and one American gammarid species (Crustacea, Amphipoda) invading Polish waters. Contrib Zool 71:411-429
Jażdżewski K, Konopacka A, Grabowski M (2004) Recent drastic changes in the gammarid fauna (Crustacea, Amphipoda) of the Vistula River deltaic system in Poland caused by alien invaders. Divers Distrib 10:81-87

Jennions MD, Blackwell PRY (1996) Residency and size affect fight duration and outcome in the fiddler crab Uca annulipes. Biol J Linn Soc 57:293-306

Jermacz Ł, Dzierżyńska A, Kakareko T, Poznańska M, Kobak J (2015a) The art of choice: predation risk changes interspecific competition between freshwater amphipods. Behav Ecol 26(2):656-664

Jermacz Ł, Dzierżyńska A, Poznańska M, Kobak J (2015b) Experimental evaluation of preferences of an invasive Ponto-Caspian gammarid Pontogammarus robustoides (Amphipoda, Gammaroidea) for mineral and plant substrata. Hydrobiologia 746:209-221

Kinzler W, Maier G (2003) Asymmetry in mutual predation: possible reason for the replacement of native gammarids by invasives. Arch Hydrobiol 157:473-481

Kinzler W, Maier G (2006) Selective predation by fish: a further reason for the decline of native gammarids in the presence of invasives. J Limnol 65:27-34

Kinzler W, Kley A, Mayer G, Waloszek D, Maier G (2009) Mutual predation between and cannibalism within several freshwater gammarids: Dikerogammarus villosus versus one native and three invasives. Aquat Ecol 43:457-464

Kley A, Maier G (2003) Life history characteristics of the invasive freshwater gammarids Dikerogammarus villosus and Echinogammarus ischnus in the river Main and the Main-Donau canal. Arch Hydrobiol 156:457-469

Kley A, Maier G (2005) An example of niche partitioning between Dikerogammarus villosus and other invasive and native gammarids: a field study. J Limnol 64:85-88

Kley A, Maier G (2006) Reproductive characteristics of invasive gammarids in the Rhine-Main-Danube catchment, South Germany. Limnologica 36:79-90

Kobak J, Żytkowicz J (2007) Preferences of invasive PontoCaspian and native European gammarids for zebra mussel (Dreissena polymorpha, Bivalvia) shell habitat. Hydrobiologia 589:43-54

Koester M, Gergs R (2014) No evidence for intraguild predation of Dikerogammarus villosus (Sowinsky, 1894) at an invasion front in the Untere Lorze, Switzerland. Aquat Invasions 9(4):489-497

Konopacka A (1998) Nowy dla Polski gatunek kiełża, Dikerogammarus haemobaphes (Eichwald, 1841) (Crustacea, Amphipoda) oraz dwa inne rzadkie gatunki skorupiaków obunogich w Wiśle.[A newgammarid in Poland, Dikerogammarus haemobaphes (Eichwald, 1841) (Crustacea, Amphipoda) and two other rare amphipods in the river Vistula]. Prz Zool 42:211-218

Krisp H, Maier G (2005) Consumption of macroinvertebrates by invasive and native gammarids: a comparison. J Limnol 64(1):55-59

Lambertini M, Leape J, Marton-Lefèvre J, Mittermeier RA, Rose M, Robinson JG, Stuart SN, Waldman B, Genovesi P (2011) Invasives: a major conservation threat. Science 333:404-405

Leuven RSEW, Van der Velde G, Baijens I, Snijders J, Van der Zwart C, Lenders HJR, Bij de Vaate A (2009) The river 
Rhine: a global highway for dispersal of aquatic invasive species. Biol Invasions 11:1989-2008

Lockwood JL, Hoopes MF, Marchetti MP (2013) Invasion ecology. Willey, New York

MacNeil C, Platvoet D (2005) The predatory impact of the freshwater invader Dikerogammarus villosus on native Gammarus pulex (Crustacea: Amphipoda); influences of differential microdistribution and food resources. J Zool 267:31-38

MacNeil C, Dick JTA, Platvoet D, Briffa M (2011) Direct and indirect effects of species displacements: an invading freshwater amphipod can disrupt leaf-litter processing and shredder efficiency. J North Am Benthol Soc 30(1):38-48

Martens A, Grabow K (2008) Das risiko der verschleppung neozoischer Amphipoda beim überlandtransport von yachten. Lauterbornia 62:41-44

Matthews J, Van der Velde G, Bij de Vaate A, Collas FPL, Koopman KR, Leuven RSEW (2014) Rapid range expansion of the invasive quagga mussel in relation to zebra mussel presence in The Netherlands and Western Europe. Biol Invasions 16:23-42

Müller O, Hertel A (2004) Abundanzentwicklung der invasiven Amphipoda Dikerogammaus villosus (Sovinski 1894) und D. $c f$. haemobaphes (Eichwald 1841) in der Deutschen Oder und den angrenzenden Kanälen (Crustacea; Amphipoda). Schriftenreihe des Bundesministeriums für Verbraucherschutz, Ernährung und Landwirtschaft (BMVEL). Reihe A Angew Wiss 498:245-249

Orlova MI, Therriault TW, Antonov PI, Shcherbina GK (2005) Invasion ecology of quagga mussels (Dreissena rostriformis bugensis): a review of evolutionary and phylogenetic impacts. Aquat Ecol 39:401-418

Otsuki H, Yano S (2014) Predation risk increases dispersal distance in prey. Naturwissenschaften 101:513-516

Platvoet D, Dick JTA, MacNeil C, Riel MC, Van der Velde G (2009) Invader-invader interactions in relation to environmental heterogeneity leads to zonation of two invasive amphipods, Dikerogammarus villosus (Sowinsky) and Gammarus tigrinus Sexton: amphipod pilot species project (AMPIS) report 6. Biol Invasions 11:2085-2093

Polis GA, Myers CA, Holt RD (1989) The ecology and evolution of intraguild predation: potential competitors that eat each other. Ann Rev Ecol Syst 20:297-330

Rewicz T, Grabowski M, MacNeil C, Bącela-Spychalska K (2014) The profile of a 'perfect' invader - the case of killer shrimp, Dikerogammarus villosus. Aquat Invasions 9(3):267-288

Ronce O (2007) How does it feel to be like a rolling stone? Ten questions about dispersal evolution. Annu Rev Ecol Syst 38:231-253

Schoener TW (1983) Field experiments on interspecific competition. Am Nat 122:240-284

Shurin JB, Allen EG (2001) Effects of competition, predation, and dispersal on species richness at local and regional scales. Am Nat 158:624-637
Simberloff D, Von Holle B (1999) Positive interactions of nonindigenous species: invasional meltdown? Biol Invasions 1:21-32

Snyder RE, Chesson P (2003) Local dispersal can facilitate coexistence in the presence of permanent spatial heterogeneity. Ecol Lett 6:301-309

Truhlar AM, Aldridge DC (2015) Differences in behavioural traits between two potentially invasive amphipods, Dikerogammarus villosus and Gammarus pulex. Biol Invasions 17:1569-1579

Vamosi SM, Heard SB, Vamosi JC, Webb CO (2009) Emerging patterns in the comparative analysis of phylogenetic community structure. Mol Ecol 18:572-592

Van der Velde G, Rajagopal S, Kelleher B, Muskó IB, Bij de Vaate A (2000) Ecological impact of crustacean invaders: general considerations and examples from the Rhine River. Biodivers Crisis Crustac 12:3-33

Van Riel MC, Van der Velde G, Rajagopal S, Marguillier S, Dehairs F, Bij de Vaate A (2006) Trophic relationships in the Rhine food web during invasion and after establishment of the Ponto-Caspian invader Dikerogammarus villosus. Hydrobiologia 565:39-58

Van Riel MC, Healy EP, Van der Velde G, Bij de Vaate A (2007) Interference competition among native and invader amphipods. Acta Oecol 31:282-289

Van Riel MC, Van der Velde G, Bij de Vaate A (2009) Interference competition between alien invasive gammaridean species. Biol Invasions 11:2119-2132

Van Riel MC, Van der Velde G, Bij de Vaate A (2011) Dispersal of invasive species by drifting. Curr Zool 57:818-827

Wang W, Feng X, Chen X (2013) Biological invasion and coexistence in intraguild predation. J Appl Math. doi:10. $1155 / 2013 / 925141$

Waser PM (1985) Does competition drive dispersal? Ecology 66:1170-1175

Weinzierl A, Potel S, Banning M (1996) Obesogammarus obesus (SARS 1894) in der oberen Donau (Amphipoda, Gammaridae). Lauterbornia 26:87-91

Wisenden BD, Rugg ML, Korpi NL, Fuselier LC (2009) Lab and field estimates of active time of chemical alarm cues of a cyprinid fish and an amphipod crustacean. Behaviour 146:1423-1442

Żytkowicz J, Kobak J (2008) Relationships between the occurrence of Chaetogammarus ischnus (Stebbing, 1898) and Pontogammarus robustoides (G. O. Sars, 1894) (Crustacea, Amphipoda) in a lowland Polish dam reservoir. Oceanol Hydrobiol Stud 37(2):39-50

Żytkowicz J, Kobak J, Kakareko T, Kentzer A (2008) Species composition and distribution of invasive Ponto-Caspian amphipods in the off-channel microhabitats of a temperate, lowland Dam reservoir. Int Rev Hydrobiol 93:62-72 